\title{
Application of Marketing Mix in Home Industry: Focussed on Micro and Small-Scale Coffee Industries
}

\author{
Lya Aklimawati ${ }^{1 *}$, Djoko Soemarno ${ }^{1)}$ and Surip Mawardi ${ }^{1)}$ \\ ${ }^{1)}$ Indonesian Coffee and Cocoa Research Institute, Jl. PB. Sudirman 90, Jember Indonesia \\ ${ }^{*}$ Corresponding author: lya.akli@gmail.com \\ Received: 30 September 2015 / accepted: 11 January 2016
}

\begin{abstract}
Differences in marketing strategies with other industries are needed to maintain business sustainability especially for facing fierce market competition. This research was aimed to identify a marketing mix implemented in micro and small scale coffee industries, and to identify external factors that affected business sustainability. This study was carried out in Sumberwringin Sub-district, Bondowoso District, East Java. Respondents of this study were 25 coffee industry players selected by using judgement sampling method. Primary and secondary data were collected in this study. Data were analyzed with descriptive-qualitative method and interactive analysis. The results showed that micro and small-scale coffee industries was still implementing conventional marketing pattern. The marketing mix which applied in coffee industry, were (a) the product mix was not persistent that depended on consumer demand; (b) selling price of product was determined from cost production and profit margins; (c) distribution was conducted with active and passive marketing particularly based on customer orders; (d) promotion mix was implemented by direct marketing, personal selling, and word of mouth. Micro-environments of the marketing affecting micro and small-scale coffee industries were: (a) customers as main target market in form of consumer markets and alternative target market as re-seller markets; (b) high intensity competition as a result of large number of competitors and lack of product diversification; (c) many raw material suppliers, but expensive input production cost; (d) there was no a marketing partnership with marketer agent/other partner, but it had strategic partnership with supplier and government; (e) government policies on product development and marketing had been implemented by facilitating exhibition activity, processing equipment, and training.
\end{abstract}

Keywords: marketing mix, micro-environment, home industry, coffee, Bondowoso

\section{INTRODUCTION}

Nowdays, industrial development is carried out through combination efforts of local resources and market potentials aligned with development policy. The efforts on industrial sector based on local resources intended primarily to boost and strengthen the economic development in the rural communities. Most industries with most local resources are small micro-scale industries or household industries. Existence of the industry group is a form of self-development in order to run economic activity based on investment opportunities. Growth of this household industry is ultimately expected to realize a fair distribution of the society income (Hafsah, 2004; Supriyati \& Syriac, 2006; Amor et al., 2010). 
Behind the rapid growth of household industry opportunities, there are great challenges that must be faced by the agents of industry. This challenge is in the form of intense business competition in small business sector to enter and have a position in the market. This business competition also occurs in micro and small scale coffee industries in entering the market of processed coffee products, considering that the market for processed coffee products are mostly played by the big industry agents which offer a variety of product quality and price (Zulkarnain et al., 1995; Marion \& Setiawati, 2015). The large varieties of coffee products boosted the small and micro-scale industries to compete with other industries that produce similar products.

Occurance of new industries in the field of coffee downstream processing, also influence the business industry in Bondowoso. This new industry began to grow in line with the economic cluster development in that area. This coffee-based business sector seems to have a fairly promising prospects (Zulkarnain et al., 1995). However, most of the coffee industries in that area were still classified as a micro and small scale industries. To face the competition in the coffee business industry, the small and micro-scale coffee industries need to organize and apply the right marketing strategies in order to sustain their business (Surya \& Setiyaningrum, 2009).

In arranging the marketing strategy, micro and small industries agents require to pay attention to the consumer behavior as it will affect product purchasing decisions. By understanding the consumer behavior, industry agents will be able to satisfy the consumer needs which changes frequently (Semuel, 2006). Changes in consumer behavior in coffee consumption were not only affected by fulfilling of functional needs, but also by other factors such as culture, social and economic (Haryadi, 2009).
To maintain and gain new consumers, industry agents have to plan marketing strategies before producing processed coffee products. Industry agents often misunderstood that consumer decisions in buying products is only based on price considerations. This assumption is not entirely correct, because consumers also consider other factors in purchasing product (Haryadi, 2009). On the other hand, knowledge about the implementation of marketing mix applied by the micro and small-scale coffee industries can be used to create a marketing strategy, primarily the right marketing mix strategy.

Discussion of the marketing mix involves four main variables, including product, price, place/distribution and promotion channels, or known as 4P. Combination of these four variables can be used as a set of tactical marketing tools which could be controlled by the industry agents in generating the desired response of the targeted markets (Kotler \& Armstrong, 2012). Meanwhile, the external factors that may affect the businesses sustainability is discussed based on microenvironmental factors such as customers, competitors, suppliers, strategic partners and Government (Hidayat \& Ghina, 2015).

Referring to the application of marketing strategy in maintaining business existence, this research aimed to identify marketing mix applied by the micro and small-scale coffee industries, and to determine external factors affecting business sustainability.

\section{MATERIALS AND METHODS}

This research was carried out in Bondowoso District, East Java on August to November 2014. Determination of the location was done deliberately, with consideration that there were small micro-scale coffee industries which started to grow in that area. In addition, Bondowoso District is one of coffeeproducing areas in East Java, consequently 
it has the potential to grow small industries based on local resources. In this study, a selected location was only limited to one sub district (Sumberwringin) due to the growth and development of industries through economic cluster program mostly implemented in this area.

Data collection used in this research was survey which was conducted through direct observation the business units and interviews with industry agents. Direct observation was done to observe and discover the coffee industry condition physically. Meanwhile, the interviews were intended to find out some information about the marketing mix strategy applied by micro and small scale coffee industries and external factors particularly the microenvironment which may influence the business sustainability. A semiopen questionnaire was used in the interview. The data collection included primary and secondary data. The primary data collected included the marketing mix which consisted of product data, price, place/distribution and promotion channels; and external factors of the micro environment including customers, competitors, suppliers, strategic partners and government. The secondary data was collected from reports, results of basic data study and literature review issued by Bank Indonesia in Jember and Indonesian Coffee and Cocoa Research Institute.

In this study, respondents of the research objects were 25 micro and small scaled coffee industry agents. Approach used in the respondents selection was a non-probability sampling with judgement sampling method. The use of this method was intended to select representative respondents and fulfill the criteria in providing the required information and agree with the research topic (Aswara et al., 2010; Nainggolan et al., 2010).

This marketing mix application research did not focus on quantitative statistical figures, because the approach used in this study was more qualitative with descriptive data interpretation. This qualitative research with descriptive method was attempted to explain the conditions in the field (Moleong, 2007; Rianse \& Man, 2009). Descriptive data on this research were elaborated in form of figures or percentages through table analysis, comply with research topic. This study also used interactive analysis of three components, namely data analysis reduction, data presentation and conclusions (Subandi, 2011; Sugiyono, 2012). Discussion of the research results in descriptive-qualitative was used to analyze whether the marketing mix applied to micro and small scale coffee industries was able to adjust the consumer expectation or not.

\section{RESULTS AND DISCUSSION}

For micro and small scale coffee industries, marketing mix strategy is a marketing tool which plays an important role in increasing sales and attracting customers. It is noted that the main players in the coffee marketing were the big industries which offers a wide range of processed coffee products to the market by adjusting its segment and target. Therefore, the micro and small scale coffee industries needs to map out a strategy in order not to lose in the tight competition of processed coffee industry. Elaboration of marketing mix and the micro-environmental conditions occured on the micro and small scale coffee industries in Bondowoso is discussed.

\section{Product Marketing Description}

The micro and small scale coffee industries in Bondowoso was starting to grow, because it was considered to give a good prospects and market opportunities. Industry agents argued that the business in coffee downstream cultivation could increase coffee products value and earn additional income. 
However, approximately $36 \%$ of the industry agents mentioned that the market conditions were likely to be stable, whereas other stated a market decline. This can be due to the increase of coffee industry in the research area, which caused a rising competition between those industries in promoting their products directly or indirectly. The micro and small scale coffee industry still had limited experience in marketing and promotion strategies. Industry agents also expressed their perception that the competitiveness of the coffee products was still weak, which was caused by expensive coffee product prices, expensive distribution cost, unattractive packaging, and without permission/product label.

Based on production capacity, the need of raw material in each industry varied widely. The average amount of raw material needed by the entire research respondents was $82.1 \mathrm{~kg} /$ month or $984.7 \mathrm{~kg} /$ year. Raw materials were processed into several products, such as coffee powder, roasted coffee and ginger coffee. However, the product generally sold by micro and small scale coffee industries was coffee powder. During this period of study, the orientation of the processed coffee marketing was still limited in domestic market especially across Java island. Only a small number of industry had sent their products to consumers outside Java, such as Bali and Sumatera. Marketing methods commonly applied throughout the industry were marketing based on order. Therefore, the downstream product marketing was still done individually. The entire research respondents had not made buy-sale contracts with buyers or other consumers.

Existence of the information technology development had not been used by the micro and small scale coffee industries. This was shown that lack of internet marketing/digital marketing usage in product marketing performed by the industry. This condition was caused by limited capacity of industry agents, low level of market orientation using electronic trading, and lack of understanding on the information technology facilities as a media marketing communications. Utilization of internet media was only $12 \%$ of the respondents. The micro and small scale coffee industries was still oriented on marketing with conventional methods, such as direct marketing, individual sales and exhibition participation. Marketing in that way required higher cost than the marketing based information technology especially in operational costs for the telephone communication cost, transportation, delivery cost and others. Therefore, the micro and small scale coffee industry agents needs to improve their knowledge and skills about marketing based on information technology in order to reach broader consumers (Supardi \& Dores, 2009; Jauhari, 2010).

Although conventional marketing was applied, there are other marketing concepts suitable with marketing methods by micro and small scale coffee industries. That marketing concept as known as entrepreneurial marketing which stated that the marketing is oriented on innovation strategy and bottom-up strategy (adjusting the product with consumer needs) (Septiani et al., 1995). This is in line with the characteristics of the coffee industry in the study location because they produced and marketed products based on consumer needs.

\section{Outlining Marketing Mix Components}

\section{Product}

Conceptually, a product is defined as something that is offered from producers to consumers to be paid, sought, bought, or consumed in order to satisfy the consumer needs and desires. It can be a tangible or intangible product. To attract the consumer interest, a product must have a superiority 
over other similar products known from their attributes which can be quality, design, brand, packaging, size, type, item/variety, taste, warranties, service and others (Kotler \& Armstrong, 2012). For coffee products, those attributes can potentially attract consumers' attention and consideration to purchase.

In this study, it was known that the micro and small scale coffee industry produced several products in forms of coffee powder, roasted coffee and ginger coffee. The main difference of this coffee powder product with others was that there was no mixed ingredients in the product such as corn, rice, or others. The produced coffee quality was quite good because it came from raw coffee beans with a reasonably good quality. Based on their quality level, the coffee beans material which was used in this industry varied widely. The processing of Arabica coffee beans was carried out with wet process, whereas Robusta coffee with dry-process. The quality of Arabica coffee beans was grouped into I up to IV quality grades. Majority of micro and small scale coffee industries used Arabica coffee beans grade II $(68 \%)$ and III (72\%). The industries which uses Arabica coffee beans with grade I was $8 \%$ and IV was $16 \%$. Meanwhile, Robusta coffee beans used in the industry were classified into various quality classes, start from grade IV (16\%), grade $\mathrm{IVb}(4 \%)$ up to unsorted and ungraded class (28\%). The survey result showed that although the quality was in unsorted and ungraded class, the coffee beans derived from red coffee cherries or red-picked beans. Industry agents explained that the quality variation in utilization of raw materials was caused by consumer needs which changed from time to time.

Considering packaging aspect, there was variation of packaging materials and size used by the micro and small scale industries. The variation of packaging was found in one industry which used transparent plastic, aluminium foil and cardboard. The use of these packaging materials was based on the type and quality of products. Majority of the industries used transparent plastic as the packaging material for coffee powder products with a percentage of $88 \%$ of industrial units. The other packaging materials used in this industry included cardboard (8\%), aluminum foil (20\%), and tight aluminum foil (4\%). Aluminum foil and tight aluminum foil were not only used to pack coffee powder products, but also for roasted coffee products. The use of these two coffee packaging types was intended for longer durability. However, the price of that packaging materials was more expensive compared to other materials, thus it potentially increases production cost and linked to the product selling price. Many of the coffee industries used transparent plastic indicated that this industry still had weak position to compete in the market.

Based on the packaging size, the coffee products produced by micro and small scale industries had a various size between $10 \mathrm{~g}$ until $1000 \mathrm{~g}$. The presence of various packaging sizes was because each industry adapting to the consumers' request. Although the packaging sizes was varying, but all the industries generally used packaging size of $100 \mathrm{~g}(20 \%)$, $150 \mathrm{~g}(12 \%), 200 \mathrm{~g}(52 \%), 250 \mathrm{~g} \mathrm{(32 \% ),} \mathrm{and}$ $500 \mathrm{~g}$. This study showed that consumers were likely interested and ordered coffee products to the industry agents with various sizes of packaging. On the other hand, most of the industry had not made the packaging professionally because the design still look very simple. This condition was also revealed in previous study of BI Jember - Puslitkoka (2010). However, there was a progress in package design because some coffee industries had their packages to be printed in Surabaya using better technology. Integration of packaging materials, packaging design and packaging size should have attractive and aesthetic contents, 
because the attractiveness of packaging has to be fulfilled in order to achieve the industrial concern and interest in attracting consumers towards their coffee products (Cenadi, 2000). Beside having the attraction elements, the attributes integration could be used as a packaging protector from damaging and used as a marketing tool in facing competition with other coffee products.

Beside the packaging aspects, the agents also need to be aware of the importance of brand for consumers. In general, the product brands were used by consumers as a consideration for purchasing. The study results of BI Jember - Puslitkoka (2010) on the brand of coffee products indicated that there was an industry which had produced coffee with certain brands. However, it was also found that there were some industries which did not have the brands for their coffee products. The results of the study also revealed that popularity of coffee products in Bondowoso was less compared to tape (fermented cassava) products. The present study showed that coffee powder or roasted coffee produced by the respondents already had trademarks which provided some information to the consumers about identity of the producer and the coffee product quality. Although it already had a trademark, the product of micro and small scale coffee industries still had a relatively low level of brand awareness, because consumers needed information to recognize the coffee product which generally came from friends or family. Low brand recognition of coffee products in Bondowoso needs attention of industry agents, because their coffee products have to complete with other coffee products which already have a high brand awareness in the market (Faisyal \& Murwani, 2008).

Result of this study suggested that the types of products produced by the micro and small scale coffee industries were still unfixed because they still followed the consumer request and tastes. A product is said to be qualified if the product could fulfill the needs and desires of consumers with the note that consumers have more experience on that product types. During the period of this study the coffee industry build the image of their product only limited on the product quality, as the result the products were not widely known by the public. Coffee products are usually only known especially by its customers. To increase the interest of the consumer, industry agents could make improvements on the production process and coffee attributes of the coffee products which will be marketed.

In maintaining the quality of its products, the coffee industry had controled the products both in terms of raw materials and finished products before being marketed. There are several steps on raw materials control, firstly the coffee beans were measured for their water content. The next step was sorting and grading before roasting process. Sorting of coffee beans was done to separate good quality beans from bad ones such as black beans, broken beans, holed beans and brown beans. In addition, the sorting was aimed to separate the coffee beans from waste or other materials, such as fruit skin, branches, gravels and others. This sorting process has to be done because the bad quality coffee beans or strange materials will affect flavor and aroma of coffee powder. In grading process, coffee beans were classified based on bean size. This process is conducted in order to achieve uniform color/roasted level at roasting process. The ultimate goal of controlling raw materials in the micro and small scale coffee industries was to produce roasted coffee beans or coffee powder with a consistent brew and taste quality. Quality control of raw materials should be done due to the results of study by BI Jember - Puslitkoka (2010) which found that the quality of brew coffee was not good and very diverse as a result of limited knowledge and equipment. 
Therefore, the coffee industry applied quality control on raw materials, and the finished products have good quality in accordance with consumer needs.

Quality control on the finished products usually was done before the coffee products were being marketed. Some efforts to control the quality of the coffee, producers test the color, aroma, taste, fineness level of coffee powder, packaging and weight of the product. The test of color, flavor and aroma of the coffee produced was carried out to match the market needs. Similarly the level of powder fineness, it was intended to acquire the flavors and aromas of the coffee to suit the consumer tastes, because the level of fineness powder is one of the factors which affect the flavor and quality of the coffee (Sri-Mulato et al., 2007). Meanwhile, the checking of product weight was needed to have precise measure of product weight. For packaging, there was also rechecking specially to control the presence of leaks which was related to taste and durability of products being sold. Besides the quality control, expired date labeling, must be added on coffee product packaging.
Based on the survey results, majority of the coffee industry still did not put expiration date label on their products. For consumers, the expire date label is an important information to know about the product before consuming. Therefore, quality control and labelling of the production are product mix strategies to provide and guarantee the product quality for consumers. The product mix strategy can also serve as one of marketing strategies in enhancing the competitive advantage of coffee products in the market (Amor et al., 2010). The efforts of quality control conducted by the micro and small scale coffee industries is presented in Table 1 .

\section{Price}

Price is one of marketing mix often being considered by consumers when purchasing the products. According to Kotler \& Armstrong (2012), price is a number of values given by consumers as an exchange medium to gain a number of benefits when having or using a product or service. In pricing, industry agents must consider the intended target

Table 1. Quality control of raw materials and coffee products conducted by micro and small-scaled coffee industry in Bondowoso district

\begin{tabular}{lcc}
\hline Criteria & Number of industries, unit & Percentage, $\%$ \\
\hline Raw material quality control & 0 & 0 \\
a. Not done & 4 & 16 \\
b. Water content measurement & 25 & 100 \\
c. Sortation & 10 & 40 \\
d. Grading & & 96 \\
Product quality control & 24 & 44 \\
a. Color test & 11 & 4 \\
b. Taste test & 1 & 12 \\
c. Aroma test & 3 & 8 \\
d. Powder fineness level & 2 & 40 \\
e. Product weight & 10 & 84 \\
f. Packaging & & 16 \\
Product label (expired date) & 21 & \\
a. No & 4 & \\
b. Yes & & \\
\hline
\end{tabular}


market and purchasing power. Based on the results of the study, most of the coffee industry (64\%) suggested that the price of the coffee products was quite expensive compared to similar products from other manufacturers. Meanwhile, 36\% coffee industry stated that their product price was cheaper than that of other coffee products. According to the perception of the $48 \%$ producers, the expensive product price was one of causes of the weak competitiveness of their products. The expensive coffee products was related to the production input prices especially the cost of raw material as coffee beans with good quality. In addition, the needs of raw material not only came from their own garden, but also from other farmers which affected total production costs.

This study result showed that the coffee industry was very concerned with large production costs because it was related with determination of product price. Although the price of coffee products from the micro and small scale coffee industries was expensive, the price was comparable to the quality of the product. The price of coffee products was closely related to their quality, meanwhile the consumer preferences towards coffee products started to grow characterized by the increase in number of critical consumers in choosing coffee products. This consumer preference leads to the quality of coffee products that can provide high satisfaction. Assessment of product quality and price affects the interest of consumer to buy (Saidani \& Arifin, 2012; Fure, 2013).

In principle, expensiveness of product depends on the perception and purchasing power of consumers and quality of products. Different from other marketing mix elements, price is an element that can change quickly due to the adaption of the consumer behavior and marketing strategies applied by producers. Price flexibility is related to benefit level gained by producers because the price is a marketing variable which plays an important role in influencing purchasing decisions and the volume of sales of the product (Tjiptono, 2008). Therefore, the micro and small scale coffee industries should pay attention to the determination of the price thus consumers will not switch to other coffee products with a more affordable price.

\section{Location/Distribution}

Location and distribution in marketing activities are quite important in providing, transporting and delivering a product or service to the final consumer. This marketing activities aim to deliver the product at the right time as a result it would be available and fulfill the needs of the consumer. In the process of distribution, producers involve other institutions to channel their products. It is also done by micro and small scale coffee industries on the research site. In product marketing, about $24 \%$ of the respondent industries distributed their coffee products through friends/family. Some industries also promoted their products by taking part in exhibition/festival facilitated by Forestry and Plantation Services of the District. Beside these distribution methods, the industries promoted the coffee based on orders or actively offered its own products to consumers. About $76 \%$ of the overall industries applied the methods. Although marketing had been done actively, only $32 \%$ of the industry applied marketing system with consignment, while others used cash and carry system. The industry applied the consignment system was those with large production volume with a wide network marketing.

Based on distribution facilities, $72 \%$ of the industries used motorcycles to carry and deliver the products if it is in small quantity. For large number, the product distribution 
was done by cars. However, distribution facility in form of car was only $12 \%$ of the industry used delivery service in distributing their products. The use of delivery service was just around $12 \%$ of the industry. On the other hand, there were $20 \%$ industries did not have any distribution facilities. In general, distribution facilities are related to the target market reached by each industry. Industry with the range of market scope of a village, usually did not use any distribution facilities because they only waited for buyers to come to the place of production. The use of vehicles generally was aimed to reach markets in districts and subdistricts. For markets scope of East Java as well as in other provinces, used delivery service to distribute the products. The percentage of the industries based on their market range is presented in Table 2. Market range outside of the city included Jember, Situbondo, Lumajang, Probolinggo, and Surabaya, while outside East Java reached Semarang, Jakarta, Bali and Sumatera.

\section{Promotion}

Promotion is a marketing activity conducted in form of communication to provide information and introducing products, as well as affecting consumers to purchase. Marketing communications covered in this promotion mix included advertising, personal selling, sales promotion, public relations/ publications, word of mouth and direct marketing (Kotler \& Armstrong, 2012). Based on this study result promotion strategies applied by the coffee industry were direct marketing, individual sales and the use of word of mouth. The three promotion methods were used because the micro and small scale coffee industries did not have any promotion facilities and capital like the major industry had in marketing the product. These limitations pushed the coffee industry to market their products directly to consumers as well as utilizing the existence of consumers as the best marketing channels, considering that most of coffee industry already had regular customers. Number of costumers of each industry, ranged from 5 to 25 people. Nevertheless, customers were employed the coffee industry to promote their products as for as the customer was satisfied with the products. This was supported by the perception of consumers that the product of micro and small scale coffee industry had quite good quality. The customer satisfaction was recommended to others by providing superiority of the coffee products. According to Silverman cit. Basalamah (2010), recommendation by customer is a marketing method and a very effective promotion tool in influencing customers to buy product. In delivering information and recommendations, there is an interaction between consumer with other consumer which led to marketing activity of product selling. This marketing communication is one of the promotional strategies called the word of mouth marketing (WOM).

Table 2. Market reach of micro and small-scaled coffee industry in Bondowoso District

\begin{tabular}{lcc}
\hline Market reach & Number of industries, unit & Percentage, $\%$ \\
\hline Village & 3 & 12 \\
Sub district & 4 & 16 \\
District & 4 & 16 \\
Out of district & 11 & 44 \\
Other Province & 3 & 12 \\
\hline
\end{tabular}


Although it is categorized as a traditional marketing methods, WOM promotion and direct marketing were considered by the micro and small scale coffee industries as media and very effective promotional strategis, because coffee is a beverage which directly involving consumers especially related flavor. Consumers who satisfied with the products of micro and small scale coffee industries will create a positive WOM where consumers share their experience enjoying coffee products to other people. Other study results revealed that the purchasing decisions of a product by $68-91 \%$ consumers was based on an advice or recommendations from other users or friends (SWA \& Nielsen Online Global Customer cit. Andriyanto \& Haryanto, 2010). For micro and small scale coffee industries, this WOM promotion was a communication which can reach consumers faster than any other promotional strategies. In addition, the industry also did not have to pay a large promotion cost to promote their coffee products. The industry either directly or indirectly used consumers as power marketing. Yuswohady cit. Basalamah (2010) mentioned that consumers were the real marketer's power because they were more trusted by customers compared to company marketers themself (the salesman). Consumers are considered reliable source because they have used the product before compared than expected consumers.

\section{Micro Environment External Factors}

\section{Buyer/Consumer}

In marketing, the presence of consumers is a very important element because they are going to buy and consume the products. Related to the marketing environment, the industry must be able to satisfy the consumers in the target markets through product mix as well as better service of marketing compared other competitors. The industry which is able to provide satisfaction to the consumers can maintain the old consumer and gain new consumers to purchase their products offered. The industry must observe the change of the consumer needs and desires of product thus the industry can adjust what is needed and desired (Andreassen \& Lindestad, 1998). The present study results showed that the micro and small scale coffee industries target market was a consumer market, because the consumers in this market brought coffee products to be consumed. As an alternative, the coffee industry tried to enter market intermediaries (reseller). By entering into this market, the industry can use the consumer service as an agent/marketers, consequently consumers can buy, promote and distributes the coffee products for resale in order to gain profit.

Based on number of customers, the respondent already had a good regular consumers which were a few until large number. However, $44 \%$ the coffee industries only had customers less than 10 people, whereas industry with many customers ( $>25$ people) only $16 \%$ of the industries. This was due to the marketing channel owned by the industry was still limited and only a few of the industry had a quite extensive marketing channel. In addition, the coffee industry categorized as micro and small scale coffee industries was only started to grow, therefore, number of their consumers was still a few. The industry condition based on the number of its customers can be seen in Table 3.

Taking into account consumer compliments, the industry had ever got a compliment from consumer that their product had coffee flavor and aromas which matched with the consumers' taste. In addition, consumers also appreciated about the product purity produced by the micro and small scale coffee industries. In production process, all industries did not use any mixing ingredients, as the result consumers could enjoy the authenticity of 
Table 3. Percentage of micro and small-scaled coffee industry based on number of customers

\begin{tabular}{lcc}
\hline Number of customer classification, people & Number of industries, unit & Percentage, $\%$ \\
\hline Few $(<10)$ & 11 & 44 \\
Moderate $(10-25)$ & 10 & 40 \\
Many $(>25)$ & 4 & 16 \\
\hline Total & 25 & 100 \\
\hline
\end{tabular}

flavor and aroma produced by coffee industry in Bondowoso. On the other hand, the coffee industry also received critics from consumers. The critics were related with the production process and product mix. From the production process, consumers claimed that the roasting process was not stable/standard which could be seen from the different level of maturity and color of the coffee powder and roasted. Besides, critics related the product mix, were price and packaging. According to the perception of consumers, the price of this coffee product was quite expensive. The expensive price of the product was usually as adjustment with raw material quality and guarantee of product purity. Consumers also gave critics about the unattractive packaging design and materials made from plastic and not professionally made by the majority of coffee industries. This conditions was also supported by the study of BI Jember - Puslitkoka (2010) that the packaging was still one of the constraints to compete with similar products in the market. Based on the results of this survey, micro and small scale coffee industries was expected to improve their coffee product mix thus may face intense competition in coffee products market.

\section{Competitors}

In national market, the micro and small scale coffee industries encontered with some constraints related with tight competition in market. This industry must compete with branded coffee products produced by small and large industries wich offered many product variety with various quality and price adjusted with target market. Currently, market segment of processed coffee products with a percentage of over $50 \%$ in national scope was still occupied by the large industries, such as PT. Nestle Indonesia, PT. Santos Jaya Abadi, PT. Mayora Indah Tbk., PT. Wings Food and other industries. Meanwhile, local markets still run by micro and small scale industries. The opportunity of micro and small scale coffee industries in local and national markets was quite large, because the positive growth of processed coffee products market. However, the marketing network expansion is still constrained by the limitations of technology and the tight competition of similar products which offered by the big industries. In addition, the national coffee industry agents also had to compete among the micro and small scale coffee industries because there was a new industry in the field of coffee processing which started to grow. The number of new businesses which started to grow in this industry pushed the micro and small scale industries to improve their products quality to fulfill the needs of the consumer. This issue was shown by coffee processing with fineness and roasted level based on consumer needs.

\section{Suppliers}

Based on the supply network, micro and small scale coffee industries was very close to the raw material sources or supplier. Raw materials for the coffee industries were obtained from farmers groups or cooperative located in Sumberwringin, Bondowoso. Most of 
the coffee industries got raw materials from their own fields. However, if the production did not fulfill the processing needs, the coffee industry bought raw materials from other farmers group or cooperative to meet the desired production capacity. It was noted that there were many raw material suppliers on the research site, therefore availability of raw materials supply for the industry could be fulfilled and sustainable. In the production process, the industry sometimes faced some problems related to the production input costs mainly raw material cost and labor. The price of raw materials and workers' salary tended to be expensive thus it would have an impact on the product selling price which was quite expensive. However, the price was adjusted with the quality of the product. On the other hand, the coffee industry treated the raw material suppliers (farmers/farmer group/cooperative) as a trading partner because the supplier plays an important role in fulfilling the supply of raw materials in their production activities.

\section{Strategic Partners}

Partners are important parts in product marketing for the industry, because they are related with business sustainability and development in the future. In general, micro and small scale coffee industries only focused on the product quality of micro and small scale coffee industries. Partnership with other parties concentrated on production and marketing areas got less attention by the industry agents. This condition was also observed in the micro and small scale coffee industries in Bondowoso, where they had not establised a cooperation with other agents/marketers to promote and market their products. They still focused on coffee quality improvement just to fulfill consumer needs, and marketed their products individually. The use of marketing agents provided some benefits for the industry, because it could reached wider market and introduce their products to the community.

The coffee industries had built strategic partnerships with suppliers, Government and banking institutions. Nonetheless, banking institutions had not been utilized optimally by the industry specially to fulfill working capital. The industry still depended on its own capital or family capital in running its business, thus production capacity and marketing was adjusted to existing capital. However, the coffee industries had close relationship with suppliers as well as government. For micro and small scale coffee industries, suppliers were the most direct and closest partners related to the production activities. Development of good relationships with the raw material suppliers was an important factor affecting marketing because the supplier delivers the value of company/ industry to consumers. That value is associated with a product mix produced by the coffee industry. The availability of raw material quality produced coffee with good quality, thus it enhanced the consumer satisfaction.

Partnership relation with Government gave some benefits to the coffee industry in product marketing. To introduce the micro and small scaled coffee industry products to the community, the Government provided some facilities when taking part in coffee exhibitions and festivals. This government facilitation was one of marketing methods used by micro and small scale coffee industries in Bondowoso, where $12 \%$ of the industries had followed coffee exhibitions or festivals to promote their products and attract customers.

\section{Government}

In order to improve the product marketing, the Government offered some regulations for product development and marketing. At this stage, form of government intervention could be directly involved in marketing products 
generated by the micro and small scale industries. Facilitation by Government, especially the marketing by involving the micro and small scale coffee industries as participants in coffee exhibitions/festivals which was intended to introduce and promote Bondowoso coffee products in a broader community. Indirectly, the facilitation provided by Government could help the industry to open a new business networks with other industries and attract new consumers.

In order to support the marketing, Government also facilitated this industry with downstream processing facilities, such as coffee roasters and grinders. Consequently the micro and small scale coffee industries could create product diversification of processed coffee, thus it could increase the intended market segment. Based on the results of this study, $16 \%$ of the coffee industries not only sold instant coffee powder, but roasted coffee beans as well. Therefore, the coffee industry market could be expanded in the future. In addition, Government did not only provide physical facilities, but also on-site services in form of training and mentoring concerning coffee downstream processing. This training aimed to improve the quality of processed coffee products both the roasted bean and flavor level, thus this could reduce the quality variation of coffee produced by the micro and small scale coffe industries. Therefore, it was noted that the micro and small scale coffee industries got the impact of Government policy implementation related with product development and marketing. Through a variety of Government assistances, the micro and small scale coffee industries could have the benefit in form of network access to a wider market within consumers.

\section{CONCLUSION}

Micro and small scale coffee industries still applied conventional marketing and did marketing mix, in terms of (a) the product mix was still not fixed due to the needs of the consumer; (b) the fixed selling cost of the product was based on basic production cost and profit margin; (c) the place/distribution mix was performed based on order and active marketing; and (d) the promotion mix was done based on direct marketing, individual sales and use of WOM. Microenvironments on the micro and small scale coffee industries, were: (a) the target market of micro and small scale coffee industries primarily was the consumer market and the alternative target market was seller's market mediator; (b) high competition intensity in the industry was a result of a large number of competitors and a lack of product diversification; (c) existence of many raw materials suppliers, but the production input costs tended to be high; (d) strategic partners had not been held a marketing cooperation with marketers agents/other parties, but it's already had a strategic partnership with suppliers and Government; and (e) government policy in product development and marketing had been implemented to micro and small scale coffee industries in form of exhibition facility, equipments and training assistance.

\section{ACKNOWLEDGEMENT}

The authors sincerely thank to the Forestry and Plantation Services of Bondowoso District and Bank Indonesia Jember for their contribution in funding and implementation of this study. 


\section{REFFERENCES}

Andreassen, T.W. \& B. Lindestad (1998). Customer loyalty and complex services: The impact of corporate image on quality, customer satisfaction and loyalty for customers with varying degrees of service expertise. International Journal of Service Industry Management, 9, 7-23.

Andriyanto, R.D. \& J.O. Haryanto (2010). Analisis pengaruh internet marketing terhadap pembentukan word of mouth dan brand awareness untuk memunculkan intention to buy. Jurnal Manajemen Teknologi, 9, 20-35.

Amor, A.; M. Hubeis \& K. Mudikdjo (2010). Kajian strategi pemasaran industri kecil sepatu (Studi kasus di Desa Ciomas, Kabupaten Bogor). Jurnal Manajemen Pengembangan Industri Kecil Menengah, 1, 58-69.

Aswara, Y.F.; F. Rahman \& A. Thoyib (2010). Analisis model kepuasan pengguna jasa transportasi kereta api eksekutif jurusan Malang-Jakarta. Wacana, 13, $1-11$.

Basalamah, F.M. (2010). Pengaruh komunitas merek terhadap word of mouth. Jurnal Ilmu Administrasi dan Organisasi, 17, 79-89.

BI Jember - Puslitkoka (2010). Kajian Pembentukan Klaster Industri Kopi di Kabupaten Bondowoso. Kerjasama Bank Indonesia Jember dengan Pusat Penelitian Kopi dan Kakao Indonesia. Laporan Internal.

Cenadi, C.S. (2000). Peranan desain kemasan dalam dunia pemasaran. Nirmana, 2, 92-103.

Faisyal \& I.A. Murwani (2008). Analisa faktor yang mempengaruhi konsumen SES $\mathrm{AB}$ dalam pemilihan merek kopi bubuk di DKI Jakarta. Journal of Business Strategy and Execution, 1, 121-134.

Fure, H. (2013). Lokasi, keberagaman produk, harga dan kualitas pelayanan pengaruhnya terhadap minat beli pada pasar tradisional Bersehati Calaca. Jurnal Riset Ekonomi,
Manajemen, Bisnis dan Akuntansi, 1, 273-283.

Hafsah, M.J. (2004). Upaya pengembangan usaha kecil dan menengah (UKM). Infokop, 25, 40-44.

Haryadi, R. (2009). Pengaruh Strategi Green Marketing Terhadap Pilihan Konsumen Melalui Pendekatan Marketing Mix (Studi Kasus pada the Body Shop Jakarta). Magister Tesis. Universitas Diponegoro, Semarang, Indonesia.

Hidayat, A.W. \& A. Ghina (2015). Identifikasi faktor internal dan eksternal penyebab kegagalan usaha pada industri tahu di Kelurahan Citeureup Kota Cimahi (Studi kasus pada usaha tahu di Kampung Sukaresmi tahun 2014). e-Proceeding of Management, 2, 1-8.

Jauhari, J. (2010). Upaya pengembangan usaha kecil dan menengah (UKM) dengan memanfaatkan e-commerce. Jurnal Sistem Informasi, 2, 159-168.

Kotler, P. \& G. Armstrong (2012). Principles of Marketing. 14 ${ }^{\text {th }}$ Edition. Prentice Hall. New Jersey, USA.

Marion, A. \& S. Setiawati (2015). Hubungan antara citra merek (brand image) kopi Kapal Api dengan perilaku konsumen. Prosiding Hubungan Masyarakat. 416-427. Bandung, Indonesia.

Moleong, L.J. (2007). Metodologi Penelitian Kualitatif. PT. Remaja Rosdakarya, Bandung.

Nainggolan, T.Y.; K. Sumantadinata \& A. Suryani (2010). Strategi pengembangan usaha "Nila Puff' dalam meningkatkan pendapatan IKM pengolahan hasil perikanan pada CV. "X" di Cibinong Bogor. Manajemen Industri Kecil Menengah, 5, 132-144.

Rianse, U. \& Abdi (2009). Metodologi Penelitian Sosial dan Ekonomi: Teori dan Aplikasi. Alfabeta, Bandung.

Saidani, B. \& S. Arifin (2012). Pengaruh kualitas produk dan kualitas layanan terhadap kepuasan konsumen dan minat beli pada Ranch Market. Jurnal Riset Manajemen Sains Indonesia, 3, 1-22. 
Semuel, H. (2006). Ekspektasi pelanggan dan aplikasi bauran pemasaran terhadap loyalitas toko moderen dengan kepuasan pelanggan sebagai intervening (Studi kasus pada hypermarket Carrefour di Surabaya). Jurnal Manajemen Pemasaran, $1,53-64$.

Septiani, S.; M. Sarma \& W.H. Limbong (2013). Pengaruh entrepreneurial marketing dan kebijakan pemerintah terhadap daya saing industri alas kaki di Bogor. Jurnal Manajemen dan Organisasi, 4, 91-111.

Sri-Mulato; S. Widyotomo \& H.K. Purwadaria (2007). Kinerja pembubuk mekanis tipe piringan (disk mill) untuk proses pengecilan ukuran biji kopi robusta pascasangrai. Pelita Perkebunan, 23, 231-257.

Subandi (2011). Deskripsi kualitatif sebagai satu metode dalam penelitian pertunjukan. Harmonia, 11, 173-179.

Sugiyono (2012). Memahami Penelitian Kualitatif. Alfabeta, Bandung.
Supardi, J. \& V. Dores (2009). Rancang bangun collaborative system pemasaran hotel secara on-line dengan pendekatan mediator based. Jurnal Sistem Informasi, $1,55-61$.

Supriyati \& E. Suryani (2006). Peranan, peluang dan kendala pengembangan agroindustri di Indonesia. Forum Penelitian Agro Ekonomi, 24, 92-106.

Surya, A. \& A. Setiyaningrum (2009). Analisis persepsi konsumen pada aplikasi bauran pemasaran serta hubungannya terhadap loyalitas konsumen (Studi kasus pada Hypermart cabang Kelapa Gading). Journal of Business Strategy and Execution, 2, 13-39.

Tjiptono, F. (2008). Strategi Pemasaran. Andi, Yogyakarta.

Zulkarnain; A. Lamusa \& D. Tangkesalu (2013). Analisis nilai tambah kopi jahe pada industri Sal-Han di Kota Palu. Jurnal Agrotekbis, 1, 493-499. 